\title{
A Study on Productivity Factors of Chinese Container Terminals
}

\author{
$\dagger$ †o $L U \cdot N a m-K y u$ Park* \\ + Department of Distribution Management, TongMyong University, Busan 608-711,Korea \\ * School of Port and Logistics, TongMyong University, Busan 608-711,Korea
}

\begin{abstract}
The container port industry has been variously studied by many researchers, because the contemporary container transportation and container port industries play a pivotal role in globalization of the world economy. For container terminals, the productivity, affected by many factors, is an important target in measuring container terminal performance. Under this background, finding the critical factors affecting the productivity is necessary. Regression analysis can be used to identify which independent variables are related to the dependent variable, and explore the relationships of them. The aim of paper is to evaluate the factors affecting the productivity of Chinese major terminals by using a regression statistical analysis modeling approach, which is to establish the variable preprocessing model (VPM) and regression analysis model (RAM), by means of collecting the major Chinese container terminals data in the year of 2008.
\end{abstract}

Key words : Chinese Container Terminal, Productivity, Variables Pre-processing Model, Regression Analysis, Critical Factor

\section{Introduction}

In Asia, more and more container terminals, especially, Chinese ports have seen a constant growth at a very high level. The fact that the strong growth of Chinese container ports is dominating port traffic not only on a regional but on a worldwide level was introduced by(Dragović et al., 2008).

Therefore, Cullinane(2006) claimed that how to keep the loyalty of customers and even appeal to more customers, also get more economic benefits is an immediate challenge and the first-question to be thinking and solving for the operators of container ports.

To maintain their competitiveness in such competitive condition, many container ports have to invest heavily in sophisticated equipment or in dredging channels to accommodate the most advanced and largest container ships in order to facilitate cost reductions for the container shipping industry.

It is important to note, however, that pure physical expansion is constrained by a limited supply of available land, especially for urban centre ports, and escalating environmental concerns. In addition, the excessive and inappropriate investment also can induce the phenomenon of inefficiency and wasting of resources. In this context, improving the berth productivity efficiency of container port appears to be a viable solution.

In terms of berth productivity, different capacity performance measures, such as berth length utilization rate (TEU/berth meter), total yard area utilization rate (TEU/total yard area), quay crane $(\mathrm{Q} / \mathrm{C})$ utilization rate (TEU/Q/C), Q/C productivity (TEU/Q/C per hour) and average quantities of $\mathrm{Q} / \mathrm{C}$ per berth etc., can be used to find the optimal capacity and throughput of container terminal.

Regarding to finding the critical factors in affecting the productivity of container terminal, Park(2008) had done the research in settling the gross berth productivity as productivity indicator, and attempted to find out the critical productivity factors of Korean container terminals.

However, the research about productivity factors of Chinese ports could not be found in literature review using regression analysis while Chinese ports are playing an essential role. Chinese ports such as Shanghai, Hong Kong, Shenzhen, Guangzhou, Ningbo, Qingdao, Tianjin, Xiamen, Dalian, are accounting for 36 percents of total volume handled by the top 25 container ports in the world in the year of 2008 (World Top Container Ports, 2008).

Therefore, this study has chosen the 15 typical container terminals of China from the top 25 container ports in the world as research objects.

In contrast with previous research, this study aims to explore the relationship among productivity indicators of Chinese container terminals and find the fact that which factors have stronger impact on productivity of container terminal. Regression analysis which has the advantages of

\footnotetext{
† Corresponding author, lubo_documents@hotmail.com 051)629-1861

* nkpark@tit.ac.kr 051)629-1861
} 


\section{A Study on Productivity Factors of Chinese Container Terminals}

analyzing the relationship between one dependent variable and several independent variables exactly, is absolute an optimal method for this study.

Therefore, in this study, the method of regression analysis is used to identify the forms of the relationship of the factors affecting the productivity. Moreover, for ascertaining the linear correlation between the independent and dependent variables, this study establishes the variable pre-processing model (VPM) which is composed of scatter diagram method and partial analysis method.

The paper is structured as follows: after the introductory section of chapter 1 , a brief literature review on previous works will be followed. Moreover, the definition of independent and dependent variables and the data collection are described in chapter 2. In chapter 3, the study establishes the variables pre-processing model and regression analysis model to get empirical results. Finally, conclusions are drawn in chapter 4.

\section{Research method}

\subsection{Literature review}

Productivity of container terminals is always been paid attention to not only researchers but also seaport managers. In recent years, many different methods had been applied to analyze it. In this section, a brief literature review of the major studies on productivity of container terminals will be undertaken.

A research has been undertaken to review the factors that affect port competitiveness actively in container traffic(Mauel, 2007), by means of the questionnaire and regression analysis model. According to the research, yard tractor, operating machine tools such as quay crane, yard crane, communication systems and container identification technique were contributed to the competitive advantage of the seaport.

Another research has been undertaken with the goal of explaining the changes of productivity in Israeli ports by using the various explanatory factors(Sachish, 1996). A linear programming model was applied for the study. With respect to the research results, the changes of volume, labor, capital, technology, management, and externality had more impact on productivity.

Recognizing the limitations in assessing the efficiency of ports solely on the basis of capital and labor investments, the four-stage DEA method had been developed (Park and De, 2004). This involves the disaggregation of the overall efficiency model into its constituent components, so that better insight can be gained into the real sources of efficiency. The model comprises individual DEA components that determine the respective efficiency related to productivity, profitability, marketability and overall. In applying their method to a sample of Korean ports, the authors conclude that improving the marketability of Korean seaports should be the utmost priority of port authorities.

Turner et al.(2004) applied DEA to the determination of changes in infrastructure productivity in North American ports over the period 1984 - 1997. They then went on to use the productivity estimates as the dependent variable within a regression model, which sought to determine the causal factors affecting the scores they derived. Perhaps most significantly, the authors conclude that there are significant economies of scale present within the North American sector, both at port and at terminal level - a finding that concurs with the outcomes of most research investigating economies of scale in the port sector. They also find that access to the rail network is a pivotal determinant of container port infrastructure productivity in North America, but that there is no evidence to suggest that specific investment in on-dock rail facilities is a productive use of the land-take involved.

By applying with AHP method, the order of the container ports in the region of southeast China had been identified (Yeo, 2002). According to the research results, the port of Hong Kong, Busan, Shanghai, Yantai, and Qingdao have stronger competitiveness. With regard to Korean container ports, the method of increasing the competitiveness is that the Korean ports need the financial investment from the Korean government, and the Korean ports also need invest the facilities and raise the service level.

According to the literature review, the method, which measures the productivity of the container terminal, is largely divided with the traditional productivity analytical method and data envelopment analysis. The traditional methods are referred to area with the facility productivity analytical method and the synthetic method of productivity. But they have difficulty in treating various variables synthetically. Compared with traditional approaches, DEA has the advantage that it can cater for multiple inputs to and outputs from the production process. However, DEA has difficulty in examining the correlation of the each variable.

Actually, the regression analysis methodology has not been applied widely to evaluate the productivity of container terminal from the previous literatures. The advantage of regression analysis is to review the relationship between one 
dependent variable and several independent variables exactly.

\subsection{Data collection and definitions of variables}

In order to determine the productivity of container terminals, many critical factors which relate to the terminal operation, are to be considered such as terminal facilities like yard area, quantities of berth, water depth, length of berth, gate, rail station and terminal equipment like $\mathrm{Y} / \mathrm{T}$, Q/C, RTGC, RMGC, reach stacker, top handler and folk lifter.

Table 1 Data collection of chinese terminals in 2008

\begin{tabular}{|c|c|c|c|}
\hline \multirow{3}{*}{ Variables } & \multirow{2}{*}{$\begin{array}{c}\begin{array}{c}\text { Dependent } \\
\text { Variable }\end{array} \\
Y \\
\end{array}$} & \multicolumn{2}{|c|}{$\begin{array}{c}\text { Independent } \\
\text { Variable }\end{array}$} \\
\hline & & $X_{1}$ & $X_{2}$ \\
\hline & $\begin{array}{l}\text { throughput } \\
\text { /per berth } \\
\text { (TEU) }\end{array}$ & $\begin{array}{c}\text { yard area } \\
\text { /per berth } \\
\left(\mathrm{km}^{2}\right)\end{array}$ & $\begin{array}{c}\mathrm{Q} / \mathrm{C} \\
/ \text { per berth }\end{array}$ \\
\hline Qingdao & 645000 & 150 & 3.3 \\
\hline Tianjin & 386363 & 167 & 2.8 \\
\hline Shenzhen & 669063 & 161 & 4.5 \\
\hline GuangZhou & 578947 & 245 & 3.1 \\
\hline Ningbo-nbct & 600000 & 252.2 & 3.3 \\
\hline Chiwan & 655556 & 138.4 & 4.1 \\
\hline Shekou & 700000 & 173.3 & 4.1 \\
\hline Nansha & 333333 & 371.7 & 3 \\
\hline COSCO-HIT & 877000 & 150 & 4 \\
\hline MTL & 817143 & 132.3 & 4.3 \\
\hline DPI & 589000 & 167 & 4 \\
\hline $\mathrm{ACT}$ & 588000 & 142.7 & 4 \\
\hline Chuanshan & 700000 & 200 & 3.6 \\
\hline Waigaoqiao-I & 1058000 & 334 & 5 \\
\hline Yanshang-I & 633333 & 278.9 & 3.8 \\
\hline \multicolumn{2}{|c|}{ Independent } & Variable & \\
\hline$X_{3}$ & $X_{4}$ & $X_{5}$ & $X_{6}$ \\
\hline $\begin{array}{c}\mathrm{T} / \mathrm{C} \\
/ \text { per berth }\end{array}$ & $\begin{array}{c}\mathrm{Y} / \mathrm{T} \\
\text { /per berth }\end{array}$ & $\begin{array}{l}\text { Length } \\
\text { /per berth } \\
\text { (m) }\end{array}$ & $\begin{array}{l}\text { water } \\
\text { depth } \\
\text { (m) }\end{array}$ \\
\hline 10.8 & 12 & 306 & 16 \\
\hline 3.9 & 12.1 & 317 & 15.5 \\
\hline 12.6 & 26.8 & 377 & 15.75 \\
\hline 6.6 & 10.5 & 275 & 12 \\
\hline 10.7 & 16.7 & 300 & 14.5 \\
\hline 12 & 23.3 & 380 & 14.5 \\
\hline 10.5 & 20.3 & 281 & 16 \\
\hline 8 & 15 & 350 & 15.5 \\
\hline 16 & 37.5 & 320 & 14.5 \\
\hline 15.1 & 27.7 & 347 & 15.5 \\
\hline 8 & 50 & 305 & 14 \\
\hline 10 & 30 & 370 & 15.5 \\
\hline 11.2 & 20.4 & 350 & 17 \\
\hline 15.6 & 33 & 313 & 13.2 \\
\hline 13.3 & 24.4 & 333 & 16 \\
\hline
\end{tabular}

Source: Inner report of 15 Chinese container terminals

This study has gathered the data from 15 Chinese major terminals in 2008 by means of direct site survey, during May 2 to Jul 3, 2009, as summarized on table 1, thus facilitating the acquisition of more reliable results and on a comprehensive scale.

By applying regression analysis, suitable productivity indicators that could be considered for evaluation of terminal operations include: handled volume of containers, quantities of vessel arrivals, income, labor, capital, technology, management and so on.

The considerable factors of this study are collected through the process of literature review, discussion with experts working in container ports for more than 20 years, and brainstorming.

The productivity indicator of this paper is defined as the handling capacity of per berth by dividing annual throughput by number of berth.

However, the selection of suitable independent variables depended on data availability and linear correlations among these variables. On this basis, yard area, the quantities of quay crane, yard crane, yard tractor, berth length, and water depth are chosen.

\subsection{Variable preprocessing model}

Before utilizing the regression analysis model, it is necessary to be aware that all of the collected factors cannot be handled as dependent variable and independent variables.

The possibility of variables duplication among the initial factors and non-linear correlation between dependent and independent variables may be existence. This study, therefore, establishes the variables pre-processing model, which is summarized in figure 1.

In the scope of the collected initial factors, first of all, the dependent and independent variables should be established. By applying with the variables pre-processing model, the duplication factors on the scope of the independent variables could be eliminated.

Furthermore, this study applies the scatter diagram and partial correlation analysis to judge the linear correlation. Then, the appropriate independent variables can be defined.

\subsection{Regression analysis model}

After the variables pre-processing, the regression analysis mode can be applied for the next analysis step.

In statistics, regression analysis includes any techniques for modeling and analyzing several variables, the focus of which is on the relationship between one dependent variable and one or more independent variables. More specifically, 


\section{A Study on Productivity Factors of Chinese Container Terminals}

regression analysis helps us understand how the typical value of the dependent variable changes when any one of the independent variables is varied, while the other independent variables are held fixed.

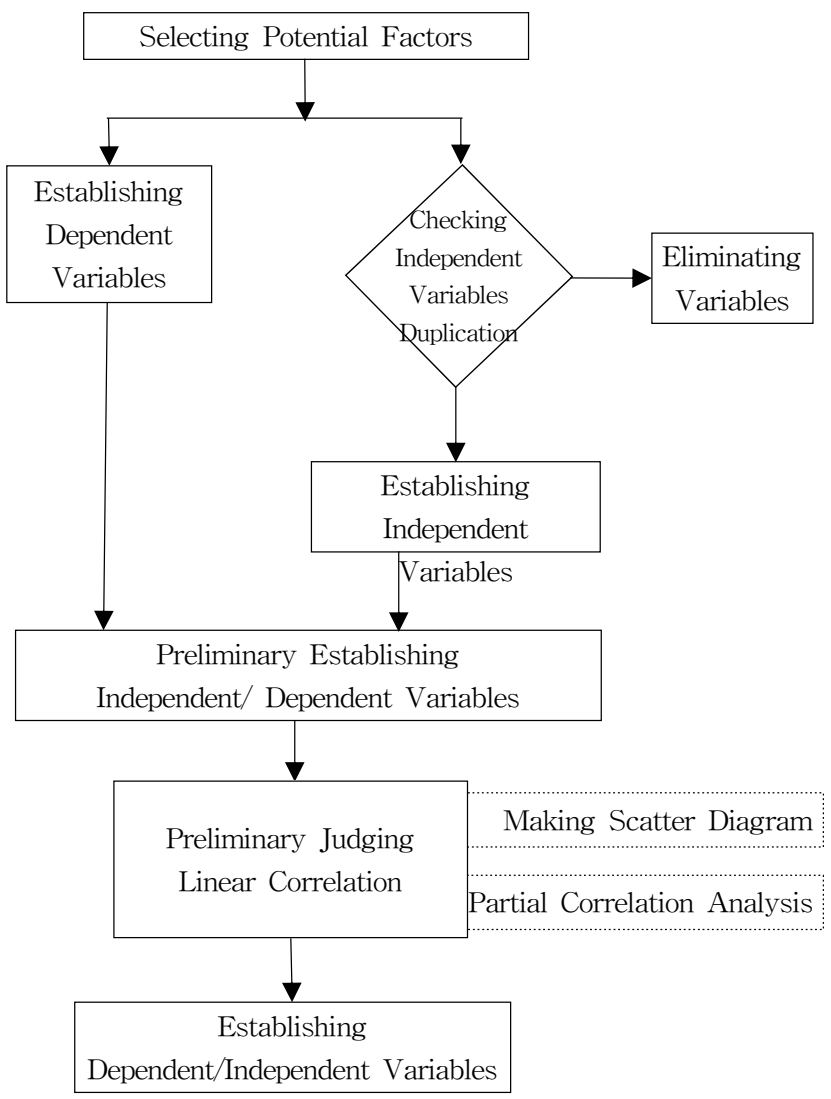

Fig. 1 Variables pre-processing model

Regression analysis is widely used for prediction and forecasting. Regression analysis is also used to understand which independent variables are related to the dependent variable, and to explore the forms of these relationships. In restricted circumstances, regression analysis can be used to infer causal relationships between the independent and dependent variables. Furthermore, the flow process of regression analysis model can be depicted as shown in figure 2 .

The procedure of model, firstly, inputs all of the selected variables, then estimates all the predictors by enter method, and backward elimination method. If all the regression coefficients are significant, the procedure stops. Secondly, the predictor with the smallest significance in the regression coefficient test will be eliminated from the model. Finally, the procedure stops, when all the regression coefficients are significant.

Then, analyzing and explaining the regression analytical results by means of the model summary $R$ value \&
Adjusted $\mathrm{R}$ square value test, ANOVA F-test, Coefficients Beta-value \& t-test. The regression formulation based on standardized coefficients can be set up.

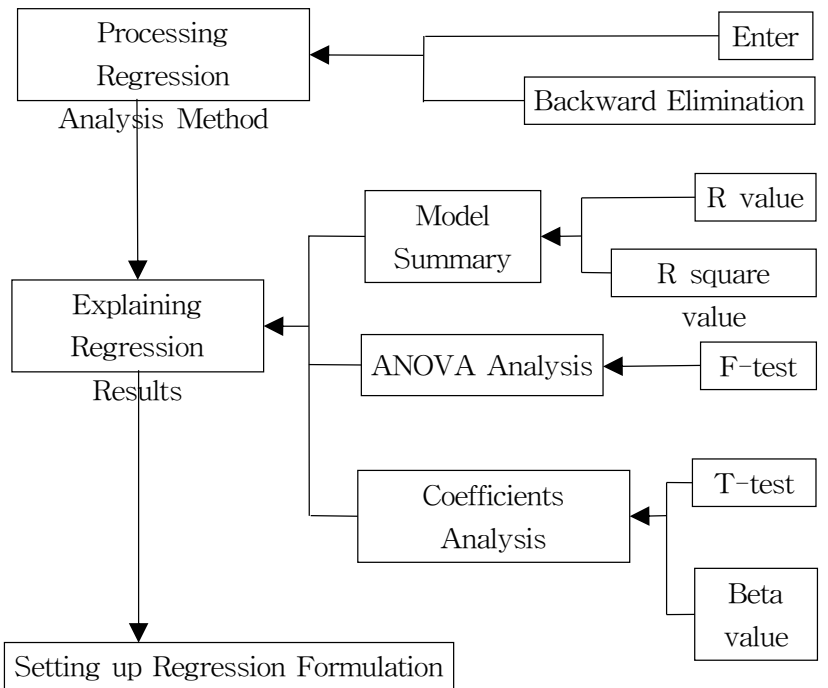

Fig. 2 Regression analysis model

\subsection{Research procedure}

The research procedure of the study is summarized in figure 3. After the selection of container terminals, the dependent variable for the study should be selected firstly. Drawing on the literature review, site survey \& interview, and brainstorming, the duplication factors could be eliminated, and also the initial independent variables can be defined. Then, by applying scatter diagram analysis and partial correlation analysis, it is possible to ascertain linear correlation of dependent and independent variables. By accomplishing the regression analysis the results of Chinese case can be summarized.

In order to provide a more comprehensive picture of research, the research results of regression analysis are interpreted with caution to explore the implication on Chinese container terminal operation. Furthermore, the previous study of Korean case is referred for comparing the affecting factors on the container terminals between two countries.

\section{Result analysis}

\subsection{Judging linear correlation of variables}

With a view to ascertaining the linear correlation between the dependent and independent variables, this study adopts the scatter diagram and partial analysis method. The scatter diagram is a type of mathematical diagram using 
Cartesian coordinates to display values for two variables for a set of data. Therefore, in this study, six sets of data scatter diagram have been made, one by one, to judge the linear correlation. From the analysis results we can draw an initial conclusion that the linear correlation between dependent and independent variables is existence as shown in figure 4.

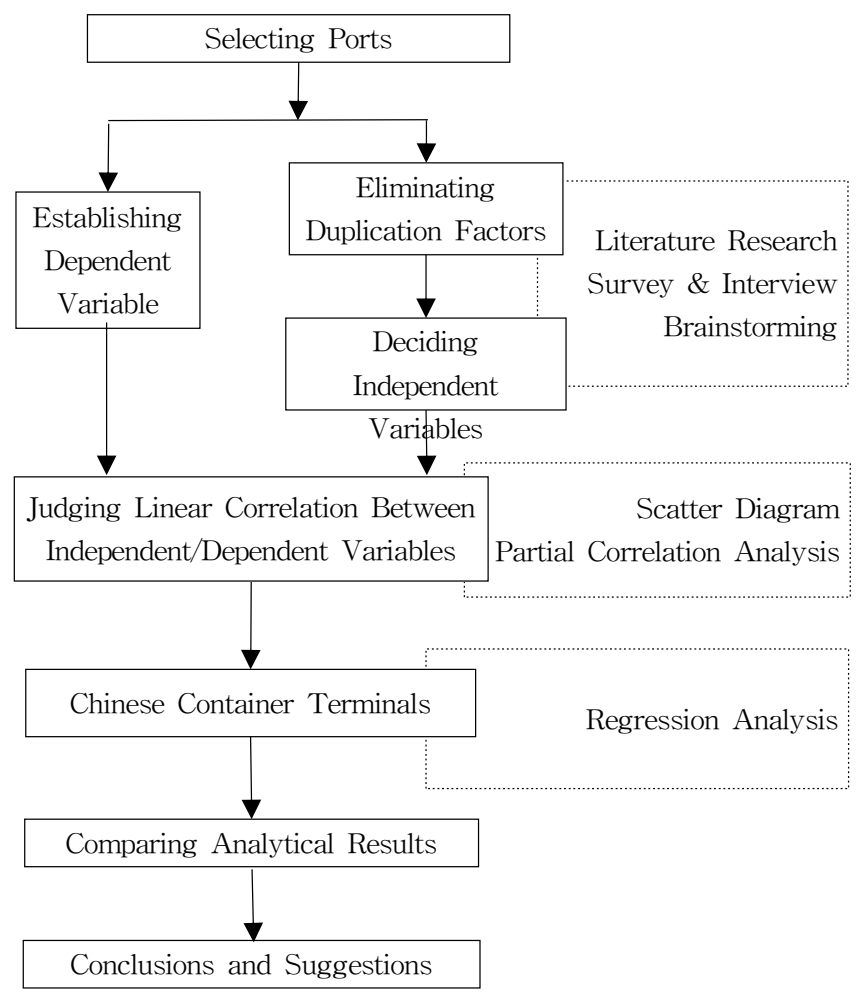

Fig. 3 Research procedure
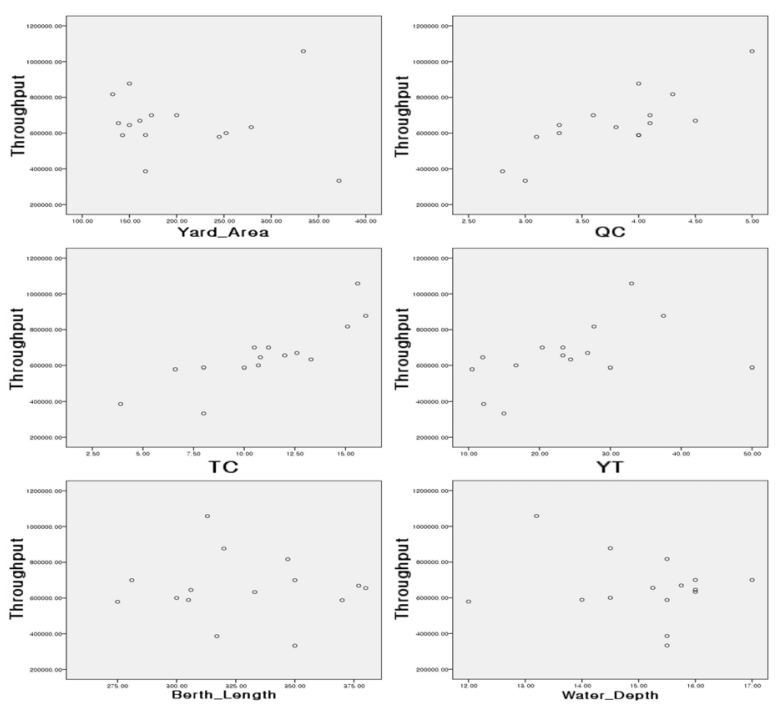

Fig. 4 Scatter diagram analysis

As table 2 shown, the partial analysis model is statistical significance. By mean of setting restrictions of control variables, the linear correlation between dependent and independent variables can be identified again. In the case of China, the analytical results indicate that, with regard to productivity, the yard area, quantities of $\mathrm{Y} / \mathrm{T}$, berth length and water depth have negative correlation; Oppositely, quantities of $\mathrm{Q} / \mathrm{C}$, quantities of $\mathrm{T} / \mathrm{C}$, quantities of $\mathrm{Y} / \mathrm{T}$, are in a state of positive correlation. Furthermore, the correlation of the quantities of $\mathrm{Q} / \mathrm{C}$, quantities of $\mathrm{T} / \mathrm{C}$, are stronger, while the correlation of yard area, quantities of $\mathrm{Y} / \mathrm{T}$, and water depth with relation to throughput per berth show weakness.

Table 2 Chinese port partial correlations analysis

\begin{tabular}{|c|c|c|c|}
\hline \multicolumn{4}{|c|}{ Chinese Port Partial Correlations Analysis } \\
\hline Variables & $\begin{array}{c}\text { Control } \\
\text { Variables }\end{array}$ & Correlation & $\begin{array}{c}\text { Sig. } \\
\text { (2-tailed) }\end{array}$ \\
\hline $\begin{array}{c}\text { Throughput } \\
\text {-Yard Area }\end{array}$ & $\begin{array}{c}\text { QC/TC/YT/ } \\
\text { Length/Depth }\end{array}$ & -.363 & .303 \\
\hline $\begin{array}{c}\text { Throughput } \\
\text {-Q/C }\end{array}$ & $\begin{array}{c}\text { Area/TC/YT/ } \\
\text { Length/Depth }\end{array}$ & .639 & .046 \\
\hline $\begin{array}{c}\text { Throughput } \\
\text {-T/C }\end{array}$ & $\begin{array}{c}\text { Area/QC/YT/ } \\
\text { Length/Depth }\end{array}$ & .798 & .006 \\
\hline $\begin{array}{c}\text { Throughput } \\
\text {-Y/T }\end{array}$ & $\begin{array}{c}\text { Area/QC/TC/ } \\
\text { Length/Depth }\end{array}$ & -.309 & .384 \\
\hline $\begin{array}{c}\text { Throughput } \\
\text {-Length }\end{array}$ & $\begin{array}{c}\text { Area/QC/TC/ } \\
\text { YT/Depth }\end{array}$ & -.637 & .048 \\
\hline $\begin{array}{c}\text { Throughput } \\
\text {-Depth }\end{array}$ & $\begin{array}{c}\text { Area/QC/TC/ } \\
\text { YT/Length }\end{array}$ & -.356 & .312 \\
\hline
\end{tabular}

\subsection{Regression analysis of productivity model}

With respect to obtaining model summary, the $\mathrm{R}$ value which means correlation coefficient.

Table 3 Regression model summary

\begin{tabular}{|c|c|c|c|c|}
\hline $\begin{array}{c}\text { Mode } \\
1\end{array}$ & $\mathrm{R}$ & $\begin{array}{c}\mathrm{R} \\
\text { Square }\end{array}$ & $\begin{array}{c}\text { Adjusted } \\
\mathrm{R} \text { Square }\end{array}$ & $\begin{array}{c}\text { Std. Error of } \\
\text { the Estimate }\end{array}$ \\
\hline 1 & $.956(\mathrm{a})$ & .914 & .850 & 68435.30785 \\
\hline 2 & $.951(\mathrm{~b})$ & .905 & .852 & 67849.71404 \\
\hline 3 & $.946(\mathrm{c})$ & .896 & .854 & 67455.15096 \\
\hline 4 & $.943(\mathrm{~d})$ & .890 & .860 & 65993.29042 \\
\hline a Predictors: (Constant), Depth, Q/C, Yard AREA, Length, Y/T, T/C \\
\hline b Predictors: (Constant), Depth, Q/C, Yard AREA, Length, T/C \\
\hline \multicolumn{5}{|l}{ c Predictors: (Constant), Water Depth, Q/C, Berth Length, T/C } \\
\hline \multicolumn{5}{|l}{ d Predictors: (Constant), Q/C, Berth Length, T/C } \\
\hline
\end{tabular}

The adjusted $\mathrm{R}$ square which means the adjusted coefficient of determination ranges from 0.850 to 0.860 , indicate that the variables explain the regression analysis model in a good fitness, in other words, the model shows 
remarkable statistical significance can be seen in table 3 .

Table 4 ANOVA analysis summary

\begin{tabular}{|c|c|c|c|c|c|}
\hline Model & & $\begin{array}{l}\text { Sum of } \\
\text { Squares }\end{array}$ & $\begin{array}{l}\text { Mean } \\
\text { Square }\end{array}$ & $\mathrm{F}$ & Sig \\
\hline \multirow{3}{*}{1} & Regression & 398621118050.97 & 66436853008 & 14.186 & .001 \\
\hline & Residual & 37467130882.763 & 4683391360 & & \\
\hline & Total & 436088248933.73 & & & \\
\hline \multirow{3}{*}{2} & Regression & 394655995675.29 & 78931199135 & 17.146 & .000 \\
\hline & Residual & 41432253258.442 & 4603583695 & & \\
\hline & Total & 436088248933.73 & & & \\
\hline \multirow{3}{*}{3} & Regression & 390586275018.08 & 97646568754 & 21.460 & .000 \\
\hline & Residual & 45501973915.646 & 4550197391 & & \\
\hline & Total & 436088248933.73 & & & \\
\hline \multirow{3}{*}{4} & Regression & 388181990751.22 & 129393996917 & 29.711 & .000 \\
\hline & Residual & \begin{tabular}{|l}
4906258182.507 \\
\end{tabular} & 4355114380 & & \\
\hline & Total & 436088248933.73 & & & \\
\hline \multicolumn{6}{|c|}{ a Predictors: (Constant), Depth, Q/C, Yard AREA, Length, Y/T, T/C } \\
\hline \multicolumn{6}{|c|}{ b Predictors: (Constant), Depth, Q/C, Yard AREA, Length, T/C } \\
\hline \multicolumn{6}{|c|}{ c Predictors: (Constant), Water Depth, Q/C, Berth Length, T/C } \\
\hline \multicolumn{6}{|c|}{ d Predictors: (Constant), Q/C, Berth Length, T/C } \\
\hline \multicolumn{6}{|c|}{ e Dependent Variable: Throughput } \\
\hline
\end{tabular}

In ANOVA analysis, according to sig. value, the $\mathrm{F}$-test which tests the integral significance of model, reflects satisfied results which are summarized in table 4 .

Table 5 Coefficients analysis

\begin{tabular}{|c|c|c|c|c|c|}
\hline \multirow{2}{*}{ Model } & \multicolumn{2}{|c|}{$\begin{array}{c}\text { Unstandardized } \\
\text { Coefficients }\end{array}$} & $\begin{array}{c}\text { Standardized } \\
\text { Coefficients }\end{array}$ & $\mathrm{t}$ & \multirow{2}{*}{ Sig. } \\
\cline { 2 - 5 } & $\mathrm{B}$ & Std. Error & Beta & $\mathrm{B}$ & \\
\hline $\begin{array}{c}\text { No.1 } \\
\text { (Constant) }\end{array}$ & 704443.916 & 316023 & & 2.229 & .056 \\
\hline Yard Area & -294.551 & 267 & -.126 & -1.101 & .303 \\
\hline Q/C & 141559.066 & 60171 & .486 & 2.353 & .046 \\
\hline T/C & 32446.965 & 8666 & .623 & 3.744 & .006 \\
\hline Y/T & -2244.915 & 2439 & -.136 & -.920 & .384 \\
\hline $\begin{array}{c}\text { Berth } \\
\text { Length }\end{array}$ & -1597.202 & 683 & -.301 & -2.338 & .048 \\
\hline Water Depth & -20072.332 & 18608 & -.143 & -1.079 & .312 \\
\hline $\begin{array}{c}\text { No.4 } \\
\text { (Constant) }\end{array}$ & 422110.04 & 193694 & & 2.179 & .052 \\
\hline $\begin{array}{c}\text { Q/C } \\
\text { T/C }\end{array}$ & 133286.615 & 44976 & .458 & 2.963 & .013 \\
\hline $\begin{array}{c}\text { Berth } \\
\text { Length }\end{array}$ & -1857.162 & 556 & -.350 & -3.340 & .007 \\
\hline a Dependent Variable: Throughput & 8003 & .592 & 3.848 & .003 \\
\hline
\end{tabular}

With regard to coefficients analysis, the t-test which tests the single variable significance of model also reflects satisfied results. However, the standardized coefficients beta value appears minus value, such as yard area, $\mathrm{Y} / \mathrm{T}$, berth length, and water depth. It means that, as throughput increasing, the independent variables should be reduced. The results are summarized in table 5 .

The regression formulation which is composed of selected variables is shown $\langle$ Formula $3>$ :

$$
\begin{aligned}
& y=30796 x_{1}+133287 x_{2}-1857 x_{3}+422110 \\
& \text { where, } x_{1}=\text { Quantities of Terminal Crane } \\
& x_{2}=\text { Quantities of Quay Crane } \\
& x_{3}=\text { Berth Length }
\end{aligned}
$$

\subsection{Implication of analysis and discussion}

There are many kinds of critical factors which relate to the productivity of Chinese container terminals. However, due to the limitation of the data collection, the independent variables are composed of yard area, the quantities of quay crane, yard crane, yard tractor, berth length, and water depth.

According to the coefficients results of regression analysis, in the scope of the independent variables, the quantities of quay crane, and yard crane and berth length have stronger affection on the productivity of per berth. The quantities of quay crane and yard crane have the positive correlation, however, berth length has the negative correlation.

According to the results of regression analysis, the following conclusions can be drawn that the more quantities of quay crane the Chinese container terminals have, the higher berth productivity will be. The situation of the yard crane is same as quay crane. The more quantities of yard crane the Chinese container terminals have, the higher berth productivity will be. With respect to berth length which has the negative correlation, as the increase of berth length, on the contrary, the productivity will decrease.

Generally speaking, the longer berth length should have the positive affection on the productivity of container terminals. With regard to the dependent variable of this study, the parts of the independent variables which exceed optimal length, are no sense.

Although this study cannot identify the optimal benchmark of the quantities of quay crane, yard crane, and berth length. Anyway, according to regression analysis, the results can conclude that the enough quantities of crane and optimal scale of berth length have strongly affection on the productivity of Chinese container terminals.

Even though, Chinese container terminals take the advantage of huge area, but the critical factors of 
productivity still should be applied reasonably. For example, the yard area per berth of Yangshan port is 1,642,000 square meters and the throughput per berth is 576,923 TEU; while the yard area per berth of Waigaoqiao port is 342,500 square meters and the throughput per berth is 975,000 TEU. In contract with the container terminals of other countries, the yard area of Chinese ports is absolute large. However, the reason why the yard area is not selected as effective independent variable is that most container terminals use the Off Dock CY area in order to improve yard utilization and quick response to customers.

With expect to results analysis of YT, the number of YT per berth of Yangshan port is 25.3 and the throughput per berth is 576,923 TEU; while the number of YT per berth of Waigaoqiao port is 22.8 and the throughput per berth is 975,000 TEU. This means that the number of YT is not related to the throughput directly. The throughput of container yard has relation to the operation of technology, labour skill and well established software.

Table 6 Results of comparative regression analysis

\begin{tabular}{|c|c|c|c|}
\hline Country & \multicolumn{3}{|c|}{ Productivity Indicator } \\
\hline Chinese Case & \multicolumn{3}{|c|}{ Throughput } \\
\hline \multirow{6}{*}{$\begin{array}{c}\text { Order of } \\
\text { Significance }\end{array}$} & 1 & Terminal Crane & (Remarkable) \\
\hline & 2 & Quay Crane & (Remarkable) \\
\hline & 3 & Berth length & (Remarkable) \\
\hline & 4 & Water Depth & \\
\hline & 5 & Yard Tractor & \\
\hline & 6 & Yard area & \\
\hline Korean Case & \multicolumn{3}{|c|}{ Throughput } \\
\hline \multirow{5}{*}{$\begin{array}{c}\text { Order of } \\
\text { Significance }\end{array}$} & 1 & Yard Tractor & (Remarkable) \\
\hline & 2 & Berth length & (Remarkable) \\
\hline & 3 & Quay Crane & \\
\hline & 4 & Terminal Crane & \\
\hline & 5 & TGS & \\
\hline
\end{tabular}

For reference (Park, 2008), comparing the results of Korean container terminals, the independent variables are different from this study. In Korean case, the yard tractor and berth length have stronger affection on the berth productivity of Korean container terminals. Therefore, the conclusion can be drawn that the factors which have affection on the productivity of container terminals are different from each country.

\section{Conclusion}

As the competition among the seaports has become increasingly fierce, every port is striving to improve its productivity and lower its operational costs. For the purpose of finding the factors that have remarkable impact on terminal productivity to enhance the berth productivity efficiency, by applying the regression analysis model, this study has chosen the major Chinese container terminals on the top of the world in 2008, extracted potential factors from literature, interview and site observation. Moreover, using variables preprocessing model and regression analysis model, the study has identified the dependent and independent variables, accomplished the regression analysis. Finally, for the sake of getting the further research results which indicate how relatively inefficient container terminals can improve their efficiency on which aspect, the study has compared the regression analytical results between Chinese and Korean container terminals.

According to the results of this study, taking advantages of large yard area and long berth length, Chinese container terminals should pay attention to increase the efficiency of yard crane and quay crane. Regarding to berth length, it is necessary to be cautiously interpreted and be kept in optimal size instead of excessive investment.

There is also some weakness existing in the research. Several factors affect terminals productivity efficiency, including the utilization of technology, number of vessel arrivals, manpower, the operational time of vessels, and so on.

However, the acquisition of data is quite difficult, and the combination of independent and dependent which are utilized in this study also has to be adjusted. If the management of each major port could collect comprehensive and detailed data with regard to its operations, that will not only help the operator increasing berth productivity efficiency, but also serve as a consultation for investigators with respect to ongoing improvement in academic research.

\section{Acknowledgements}

"This research was supported by the MKE(The Ministry of Knowledge Economy), Korea, under the ITRC(Information Technology Research Center) support program supervised by the NIPA(National IT Industry Promotion Agency"(NI PA-2009-C1090-0902-0004)

\section{References}

[1] Acosta, M.(2007), "Port Competitiveness in Container Traffic from an Internal Point of View: the Experience of the Port of Algeciras Bay", Journal of MARIT.POL.MGMT., Vol. 34, No.5, pp. 501 520. 
[2] Arie, S.(1996), "Productivity functions as a managerial tool in Israeli ports", Journal of MARIT.POL.MGMT., Vol. 23, No.4, pp. 341 369.

[3] Chen, Y.(2006), "Europe and Asia Standard Container Berth Production Technology Application Comparative Analysis", Journal of China Water Transport. Vol.11, No.4.

[4] Cullinane, K., Wang, T.F., Song, D,W., and Ping J.(2006), "The technical efficiency of container ports: Comparing data envelopment analysis and stochastic frontier analysis", Journal of Transportation Research Part a, Vol.40, pp. 354 374.

[5] De, P.(2006), "Total Factor Productivity Growth: Indian Ports in the Era of Globalization”, Journal of Maritime Economics \& Logistics.

[6] Dragović, B., and Park, N.K.(2008), "Container port capacity performance-case study: major European and Asian ports", IAME conference.

[7] GU, M.(2006), "Singapore, a sustainable development container port”, Journal of Port Economy. Vol.2, No.23.

[8] Park, N.K., Lee, S.W., Choi, H.R. and Kwon, H. K.(2004), "A Simulation Model for Improving the Productivity of Container Handling in the Container Terminal", International Journal of Navigation and Port Research, Vol.28, No.4, pp. 285 291.

[9] Park, R.K., and De, P.(2004), "An alternative approach to efficiency measurement of seaports", Journal of Maritime Economics and Logistics, Vol.6, pp. 53 69.

[10] Park, N.K. and Kim, J.Y.(2008), "Critical Factors for Container Terminal Productivity", Journal of Korean Navigation and Port Research Vol.33, No.2, pp. 153 159.

[11] Peng, C.S.(2007), "Application of Computer Simulation to Modification and Expansion Project of Bulk Terminal", Journal of Port \& Waterway Engineering, Vol.4, No.13.

[12] Turner, H., Windle, R., and Dresner, M.(2004), "North American containerport productivity: 1984 -1997", Journal of Transportation Research E, Vol.40, pp. 339 356.

[13] World Top Container Ports.(2008), Journal of CONTAINER MANAGEMENT, 2009.

[14] Yeo, T.K.(2002), "An Evaluation of the Competitiveness of Chinese Container Ports", Asian Journal of Shipping and Logistics, Vol.- No.34, pp. 39 60.

Received 9 June 2010

Revised 15 September 2010

Accepted 17 September 2010 